\title{
Budaya Demokrasi Sebagai Bentuk Upaya Peningkatan Kehidupan Berbangsa
}

\author{
Aprillia Nuril Hidayanti \\ Institut Ilmu Kesehatan Strada Indonesia \\ hidayantiaprillia07@gmail.com
}

\begin{abstract}
Abstrak
Demokrasi merupakan isu yang sudah lama ramai diperbincangkan. Ide demokrasi ini muncul dalam bahasa Yunani sekitar dua ribu lima ratus tahun yang lalu. Sekarang pelaksanaan demokrasi terus dikembangkan untuk mendapatkan penampilan yang terbaik. Konstitusi Indonesia menyatakan demokrasi sebagai sistem dalam menjalankan pemerintah. Dengan demikian, konsekuensi dari pilihan ini harus diterapkan secara imperatif. Di dalam kehidupan berbangsa dan bernegara ternyata banyak masalah yang muncul akibat pelaksanaan demokrasi. Demokrasi tidak dapat dipahami sebagai sistem politik. Pada dasarnya sistem ini mengatur begitu banyak kepentingan dalam masyarakat seperti negara dan warga negara. Jadi sistem seperti itu harus dibantu oleh budaya pendukung. Tulisan ini mencoba mendeskripsikan budaya seperti apa yang harus dikembangkan di Indonesia. Budaya ini ditanggung secara mental dan sikap moral. Berdasarkan Pancasila sebagai falsafah bangsa Indonesia. Tidak hanya menyebabkan demokrasi berjalan dengan baik, tetapi juga menjaga demokrasi tidak kehilangan eksistensi dan esensi. Akhirnya, demokrasi memberikan keuntungan bagi rakyat sebagai pemilik kedaulatan. Karena demokrasi meripakan permerintahan dari rakyat, oleh rakyat, dan untuk rakyat.
\end{abstract}

Kata Kunci : Demokrasi, Upaya, Berbangsa

\section{Latar belakang}

Negara merupakan suatu

menterinya. Terbentuknya suatu organisasi yang di dalamnya terdapat wilayah, masyarakat, dan pemerintah. negara harus mempunyai tiga syarat Negara dikatakan suatu organisasi karena di dalamnya terdapat stuktur contohnya presiden yang dibantu oleh utama yaitu wilayah, masyarakat, dan pemerintah. Setiap negara memiliki sistem atau bentuk pemerintahan wakil presiden dan menteri tersendiri. Bentuk-bentuk pemerintahan itu diantaranya 
Oligarki,Anarki, Moboraksi, Diktator, dan Demokrasi.

Indonesia adalah negara yang menjunjung tinggi demokrasi, di Asia Tenggara, Indonesia adalah negara yang paling baik menjalankan demokrasinya. Demokrasi adalah kekuatan rakyat atau suatu bentuk pemerintahan dengan rakyat sebagai pemegang kedaulatannya. Dari beberapa bentuk pemerintahan ini, demokrasi yang paling umum digunakan dalam suatu sistem pemerintahan termasuk Indonesia.

Konsep demokrasi menjadi sebuah kata kunci tersendiri dalam bidang ilmu politik. Hal ini menjadi wajar, sebab demokrasi saat ini digadanggadang sebagai indikator perkembangan politik suatu negara. Berbicara mengenai demokrasi didalamnya memperbincangkan tentang kekuasaan, atau lebih tepatnya pengelolaan kekuasaan secara beradab. Di Indonesia sendiri, demokrasi telah melewati banyak fase dimana demokrasi berkembang sesuai perkembangan zaman. Dalam pelaksanaannya, demokrasi selalu menimbulkan pro dan kontra, baik. dalam kebijakan maupun realisasinya.

Demokrasi adalah masalah yang sudah lama diperbincangkan. Ide yang muncul kira-kira 2500 tahun yang lalu di Athena sampai sekarang masih tetap diperbincangkan secara anthusias. Sampai saat ini praktek demokrasi terus berkembang mencari formatnya yang paling baik. Bangsa Indonesia secara konstitusional telah memilih demokrasi sebagai sistem penyelengaraan pemerintahan negara. Sebagai suatu pilihan sistem ini secara imperatif harus dilaksanakan. Dalam kenyataannya banyak sekali muncul permasalahan akibat dari penerapan demokrasi di Indonesia.

\section{Kasus/Masalah}

Indonesia merupakan negara yang majemuk. Terdiri dari berbagai suku bangsa dan latar belakang yang berbeda dari setiap penduduknya. Jumlah penduduk yang sangat banyak mengharuskan pemerintah Indonesia harus adil dalam memerintah dan menentukan kebijakan. Demokrasi dirasa sebagai jalan yang benar untuk menunuju 
suatu keadilan untuk rakyat. Namun, didalam pelaksanaanya terdapat berbagi kendala. Demokrasi dijadikan satu pasak untuk mendirikan pilar-pilar dalam kehidupan berbangsa dan bernegara. Oleh karena itu demokrasi saat ini dijadikan sebagai salah satu usaha untuk meningkatan keharmonisan dalam kehidupan berbangsa dan bernegara.

1. Bagaimana penerapan sistem demokrasi di Indonesia?

2. Apa manfaat demokrasi bagi kehidupan berbangsa dan bernegara

\section{Tinjauan Pustaka.}

Menurut Mas'oed (1999:6),demi kelestarian demokrasi diperlukan sebuah kesepakatan dari rakyat mengenai makna demokrasi itu sendiri dari segi mekanisme kerja demokrasi dan kegunaan demokrasi bagi kehidupan. Kekuatan demokrasi berasal dari kehendak rakyat sendiri bertujuan untuk mencapai kebaikan bersama sehingga persoalan demokrasi berkaitan dengan persoalan terakomodirnya atau keterwakilan kehendak rakyat itu sendiri

Mengutip teori dari Rousseau (2007), demokrasi adalah tahapan yang harus dilewati bagi negara jika ingin sejahtera.
Pernyataan ini merujuk bahwa demokrasi sebagai acuan bagi semua negara jika ketatanegaraan suatu negara ingin sempurna. Kemudian Rousseau menambahkan bahwa kesepurnaan bukanlah milik manusia begitupun demokrasi. Demokrasi dimaknai bukan sebagai tujuan akhir namun lebih melihat kepada fakta tahapan yang ada atau sedang berlangsung. Demokrasi akan berjalan beriringan dengan berkembangnya zaman dan dipengaruhi oleh budaya sebuah negara. Sehingga jika demokrasi diterapkan secara kaku dan terlalu ideal, demokrasi yang nyata tidak akan terwujud

\subsection{Konsep dan Hakikat Demokrasi}

Kata "demokrasi" secara harfiah berasal dari bahasa Yunani, yakni "demos" (masyarakat) dan "kratia" (aturan atau kekuasaan) dan demokrasi berarti kekuasaan di tangan rakyat. Dengan demikian demokrasi dapat diartikan sebagai sistem pemerintahan yang berlawanan dengan sistem pemerintahan yang hanya di tangan seseorang (monarchi atau tirani) atau pemerintahan yang dipimpin oleh 
beberapa orang saja (aristokrasi atau oligarki) (Dahl, dalam Fachrudin, 2006:26).

Lebih empiris-aplikatif di dalam "The Advanced Learner's Dictionary of Current English (Hornby, et al., 1962:261) dikemukakan bahwa yang dimaksud dengan "democracy" adalah : a) Country with principles of government in which all adult citizens share through their ellected representatives; b) Country with government which encourages and allows rights of citizenship such as freedom of speech, religion, opinion, and association, the assertion of rule of law, majority rule, accompanied by respect for the rights of minorities. c) Society in which there is treatment of each other by citizens as equals"

\subsection{Prinsip Demokrasi}

Demokrasi adalah bentuk pemerintahan yang dimana tentunya terdapat prinsip-prinsip di dalamnya. Berikut ini ulasan lengkap mengenai prinsip-prinsip demokrasi :

- Negara berdasarkan konstitusi

- Peradilan tidak memihak dan bebas
- Kebebasan berpendapat dan berserikat

- Adanya pergantian pemerintahan

- Kedudukan rakyat sama di mata hukum

- Adanya jaminan hak asasi manusia

- Adanya kebebasan pers

\section{Pembahasan}

4.1.Penerapan Sistem Demokrasi di Indonesia

Pada tahun 1998 merupakan babak baru pada sistem politik di Indonesia, karena di tahun itu tradisi demokrasi dalam semua proses pemerintahan politik negara ini dimulai. Setelah hampir 32 tahun negara Indonesia didominasi oleh sistem pemerintahan politik yang militer, maka pada era itu Indonesia melepaskan proses sistem politik negara yang dominative.

Dengan adanya perubahan itu tentu banyak keuntungan yang diraih. Keberhasilan reformasi ini berakibat pada terbentuknya puluhan partai oleh golongan masyarakat yang memiliki latar belakang ideologi, aspirasi serta tradisi politik yang bervariasi. Terjadi liberalisasi media 
massa yang sangat luas dan leluasa dalam memperoleh dan menyebarkan informasi kepada khalayak.

Pemerintah tidak menghalangi rakyat yang menyuarakan aspirasi, memberi kritik dan saran kepada pemerintahan saat itu. Indonesia juga menyelenggarakan pemilu pertama kali pada tahun 1999, 2004 dan yang akan terjadi setiap 5 tahun sekali. Dengan adanya pemilu dapat mempertegas arah demokrasi yang akan berjalan sesuai rencana dan mampu membuat negara Indonesia menjadi negara demokrasi.

\subsection{Manfaat demokrasi dalam kehidupan} berbangsa dan bernegara

Demokrasi merupakan sistem yang telah lama dianut oleh bangsa indonesia walaupun sudah beberapa kali berganti jenis. Tentunya demikrasi memberio manfaat tersendiri bagi kehidupan berbangsa dan bernegara. Adapun manfaatnya adalah sebagai berikut :

- Menjamin hak-hak dasar

- Adanya kesetaraan setiap warga negara

- Pemenuhan kebutuhan umum
- Pembaharuan kebijakan sosial

- Kebebasan rakyat untuk menyampaikan pendapat

- Mencegah tirani

- Mencegah terjadinya pemerintahan yang dictator

- Menciptakan pemerintah yang bertanggungjawab

- Meningkatkan Kerjasama antar warga negara

- Membuat masyarakat lebih tanggungjawab

\section{Kesimpulan}

Sampai saat ini praktek demokrasi terus berkembang mencari formatnya yang paling baik. Bangsa Indonesia secara konstitusional telah memilih demokrasi sebagai sistem penyelengaraan pemerintahan negara. Sebagai suatu pilihan sistem ini secara imperatif harus dilaksanakan. Dalam kenyataannya banyak sekali muncul permasalahan akibat dari penerapan demokrasi di Indonesia. Sebagai suatu sistem harus ditopang demokrasi sebagai budaya 


\section{Daftar Pustaka}

https://www.kompasiana.com/regina 19507/615eff1c0101907ee0362de2/p

enerapan-sistem-demokrasi-di-

indonesia

Mujani, S. (2007). Muslim demokrat:

Islam, budaya demokrasi, dan partisipasi politik di Indonesia pasca

Orde Baru. Gramedia Pustaka Utama.

Wilujeng, S. R. (2014).

Meningkatkan Kualitas kehidupan berbangsa melalui budaya

Demokrasi. HUMANIKA, 19(1), 145157.

Syartika, R. (2019). Makalah

Demokrasi Indonesia.

http://eprints.uad.ac.id/9437/1/DEM

OKRASI\%20dwi.pdf

https://hot.liputan6.com/read/449153

3/macam-macam-demokrasi-

pengertian-prinsip-dan-ciri-cirinya-

yang-perlu-diketahui
Siyoto, S., \& Sodik, M. A. (2015). Dasar metodologi penelitian. Literasi Media Publishing.

Sodik, M. A., \& Nzilibili, S. M. M. (2017). The Role Of Health Promotion And Family Support With Attitude Of Couples Childbearing Age In Following Family Planning Program In Health. Journal of Global Research in Public Health, 2(2), 8289.

Hidayanti, A. N. (2021). Menjaga Eksistensi Pancasila Dan Penerapannya Sebagai Upuya Memupuk Rasa Nasionalisme Bangsa Di Era Globalisasi.

Hidayanti, A. N. Pemberian Vaksinasi Covid-19 Kepada Masyarakat Sebagai Wujud Pemenuhan Hak Asasi Manusia Di Bidang Kesehatan. 